\title{
Application of Organic Inhibitors to the Corrosion of Materials AISI 1070 Steel
}

\author{
aDestri Muliastri*, aDevi Eka S, aNaufal Afif, aVania Tinting Sirenden, bJanuar Nur \\ Rohmah Suprihartini
}

aDepartment of Mechanical Engineering, Politeknik Negeri Bandung, Bandung 40012, Indonesia

bInterdisciplinary Division of Nanoscience and Technology, Graduate School, Chulalongkorn

University, Pathum Wan District, Bangkok 10330, Thailand

Received 31 October 2020; accepted 12 March 2021

\begin{abstract}
AISI 1070 steel is a material that has corrosion when it reacts with the environment. One way to inhibit the corrosion rate is by using organic inhibitors. The organic inhibitors used mango leaves and mango rinds with variations in the concentration of organic inhibitors of $0 \%, 6 \%$, and $8 \%$, respectively. This study aimed to determine the effectiveness of mango leaf extract and mango rinds as an inhibitor against the corrosion rate of AISI 1070 Steel. The extraction was carried out using the Maceration Method. Fourier Transform Infrared (FTIR), Potenzyodinamic, and Weight Loss tests were carried out in this study. FTIR results show that both mango rinds and mango leaf have ingredients that were able to inhibit the corrosion rate, such as flavonoid functional groups including $\mathrm{C}-\mathrm{H}, \mathrm{C}=\mathrm{O}$, and $\mathrm{C}-\mathrm{O}$.

Using the weight-loss method, the best corrosion rate was found in the mango rinds extract with a concentration of $8 \mathrm{~mL}$, which was $31.784 \mathrm{~mm} /$ year with an inhibition efficiency of $92 \%$. The highest corrosion rate was in $2 \mathrm{M} \mathrm{H}_{2} \mathrm{SO}_{4}$ solution using potentiodynamic, without a mixture of inhibitors, that is $0.15589478 \mathrm{~mm} /$ year.
\end{abstract}

\section{KEYWORDS \\ Corrosion \\ Mango leaves \\ Mango skin \\ Extraction \\ Organic inhibitors}

\section{INTRODUCTION}

In the world of industry, especially the industry that produces materials, it always experiences losses. This is because about $70 \%$ of the material produced has failed in the forming process. The form of failure experienced is the occurrence of oxidation in the material, which causes the quality of the material to decrease, known as corrosion.

Corrosion is damage resulting from a chemical reaction between an alloy in an environment (Kurniawan, 2015). The material will experience a change in properties, or the ability of the material will be reduced. Corrosion is seen as an event or reaction of the compound back to its original form (Pierre, 2008). The occurrence of corrosion is due to the main elements that support the corrosion reaction to take place. These elements include anode, cathode, the reaction between anode and cathode, and electrolytes. 
Maceration is an extraction process by immersing a sample using an organic solvent at room temperature. This process is very beneficial in the process of isolating organic compounds from natural materials because the sample immersion will occur in the cell walls and membranes due to pressure inside and outside the cell so that secondary metabolites in the cytoplasm will dissolve in organic solvents. Moreover, the compound structure will not be easily damaged. (Harborne, 1984). The concentration of corrosive substances is related to the $\mathrm{pH}$ or acidity and basicity of a solution. Acidic solutions are very corrosive to metals, where the metal in the acidic solution media will corrode more quickly because it is an anode reaction. Meanwhile, alkaline solutions can cause corrosion in the cathode reaction because the cathode reaction is always simultaneous with the anode reaction (Djaprie, 1995).

AISI 1070 steel material is a steel material that has a carbon content of $0.07 \%$, which is very susceptible to corrosion when interacting with the environment. Material is an anode in the event of corrosion. Anooda is part of a reaction that will undergo oxidation. The material that acts as an anode has the release of electrons from neutral metal atoms to form ions. (Heru, 2017). The organic inhibitor is an inhibitor derived from nature that is easy to find and has a relatively cheap cost. The use of natural materials is needed. Several organic inhibitors have been used to inhibit the rate of corrosion, including guava leaves, papaya leaves, coffee beans, tea leaves, mango rinds and others.

Heru (2017) has conducted research related to the application of lime rinds extract as an organic inhibitor for API $5 \mathrm{~L}$ steel in $2 \mathrm{M} \mathrm{H}_{2} \mathrm{SO}_{4}$ solution the obtained a polarization test of 99.238\%. Rizaq (2017) has applied mango rinds as an organic inhibitor on API 5L steel in HCl media, decreasing the corrosion rate by $81.7711 \%$. The effect of adding orange peel extract and mango peel as a corrosion inhibitor to carbon steel in a 3.5\% $\mathrm{NaCl}$ medium was carried out by Tubagus (2015). The corrosion rate obtained for the orange peel with a concentration of $400 \mathrm{ppm}$ was 0.60 mpy and peeled mango. With a concentration of $600 \mathrm{ppm}$ obtained a corrosion rate of 1.0 mpy.

The rate of corrosion is strongly influenced by the inhibitor used. Mango rinds and mango leaves are among the most common plants. Mango rinds and mango leaves contain flavonoids that can inhibit the corrosion rate. Inhibition of the corrosion rate of AISI 1070 steel material using mango leaf extract inhibitor and mango rinds in this study was able to inhibit the corrosion rate.

\section{METHODS}

\section{Inhibitor Preparation}

The physic-chemical analysis of mango leaves and mango rinds and the results should be compared with existing inhibitor(s). are processed into powder, dried in the open air for approximately ten days. After the water content is lost, then blend until it becomes a powder with a mass of 350 grams. For mango leaves after drying, blend until it becomes a powder of 400 grams. 


\section{Mango Rinds Inhibitor Extraction}

Mango Rinds powder is stored in a plastic container size of 5 liters. Then powdered mango rinds maceration process is carried out using the immersion as much as 4 liters of ethanol during $5 \times 24$ hours. After the immersion process is carried out, the filtrate and residue separation is carried out using filter paper. The filtrate evaporated for ten days, and then the evaporated product in the form of extract oil is used as an inhibitor.

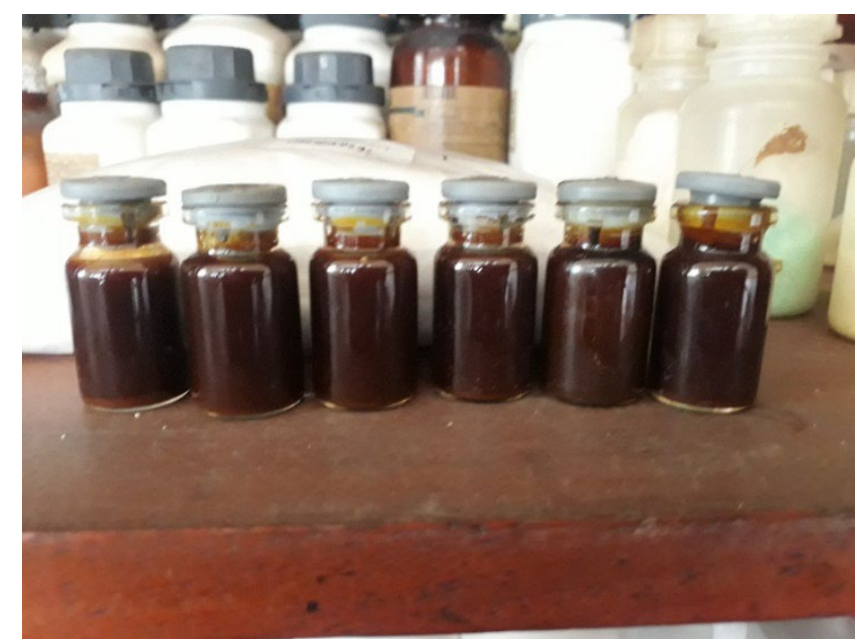

Figure 1. Mango Rinds Extraction

\section{Mango Leaf Inhibitor Extraction}

The powdered mango leaves are stored in a 5-liter plastic container, then the mango leaf powder is macerated, which is soaking in 4 liters of ethanol for $5 \times 24$ hours. After the immersion process is carried out, the filtrate and residue separation process is carried out using filter paper. The filtrate evaporated for ten days, and then the evaporated oil extract is used as an inhibitor.

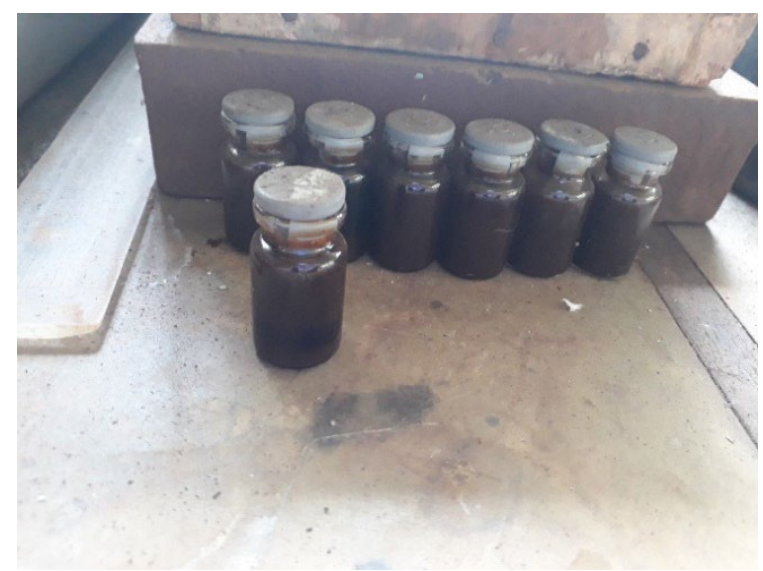

Figure 2. Mango leaf inhibitor extraction 


\section{Preparation of Electrolyte Solutions}

The electrolyte solution used $\mathrm{H}_{2} \mathrm{SO}_{4} 2 \mathrm{M}$. This solution is obtained by mixing $111 \mathrm{~mL} \mathrm{H} 2 \mathrm{SO}$, which is placed in a $1000 \mathrm{~mL}$ volume flask.

\section{Potentiodynamic Polarization Testing}

The AISI 1070 steel sample used in this polarization test has dimensions of $2 \mathrm{~mm} \times 2 \mathrm{~mm}$. The potentiodynamic polarization testing procedure begins by preparing Aisi 1070 steel material with a $2 \mathrm{~mm} \times 2 \mathrm{~mm}$ contact surface and $2 \mathrm{M} \mathrm{H} 2 \mathrm{SO} 4$ solution and varying concentrations of mango leaf and mango rinds inhibitor. Then the electrolyte solution is put into a measuring cup of $100 \mathrm{ml}$ and inserting an organic inhibitor with the same concentration. The working electrode, the auxiliary electrode, and the reference electrode are installed in the tool circuit.

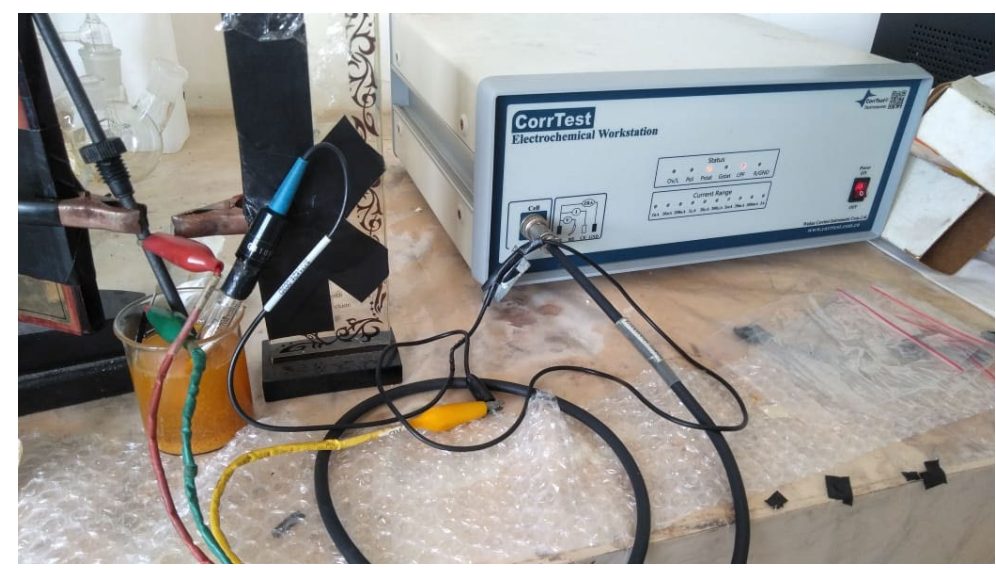

Figure 3. Potenzyodinamic Testing

\section{Weight Loss Testing}

The weight-loss method calculates corrosion by using the difference between the initial weight and the final weight. This method is used to obtain the corrosion rate. Where the weight of the material before immersion in the corrosive solution is weighed first, and after soaking it is weighed again. The immersion test is in accordance with the ASTMG 31-72 standard (Kurniawan, 2015).

The corrosion rate equation can be shown in the following equation:

$$
\text { Corrosion Rate }=\frac{K \times W}{A \times T \times D}
$$

Where

$K$ : Constant

$T$ : Time of exposure 
$A$ : Surface Area $\left(\mathrm{cm}^{2}\right)$

$W$ : Weight Loss (gram)

$D$ : Density $\left(\mathrm{gr} / \mathrm{cm}^{3}\right)$

(Dariva,2014)

\section{RESULTS AND DISCUSSION}

\section{Results of Organic Inhibitor FTIR Testing}

FTIR testing was carried out on mango rinds and mango leaf extracts. In previous studies, mango rinds and mango leaves contained antioxidants, namely flavonoids. Flavonoids are compounds that can inhibit the rate of corrosion. The results of the FTIR analysis of mango leaf extract and mango rinds can be seen in Figure 4.

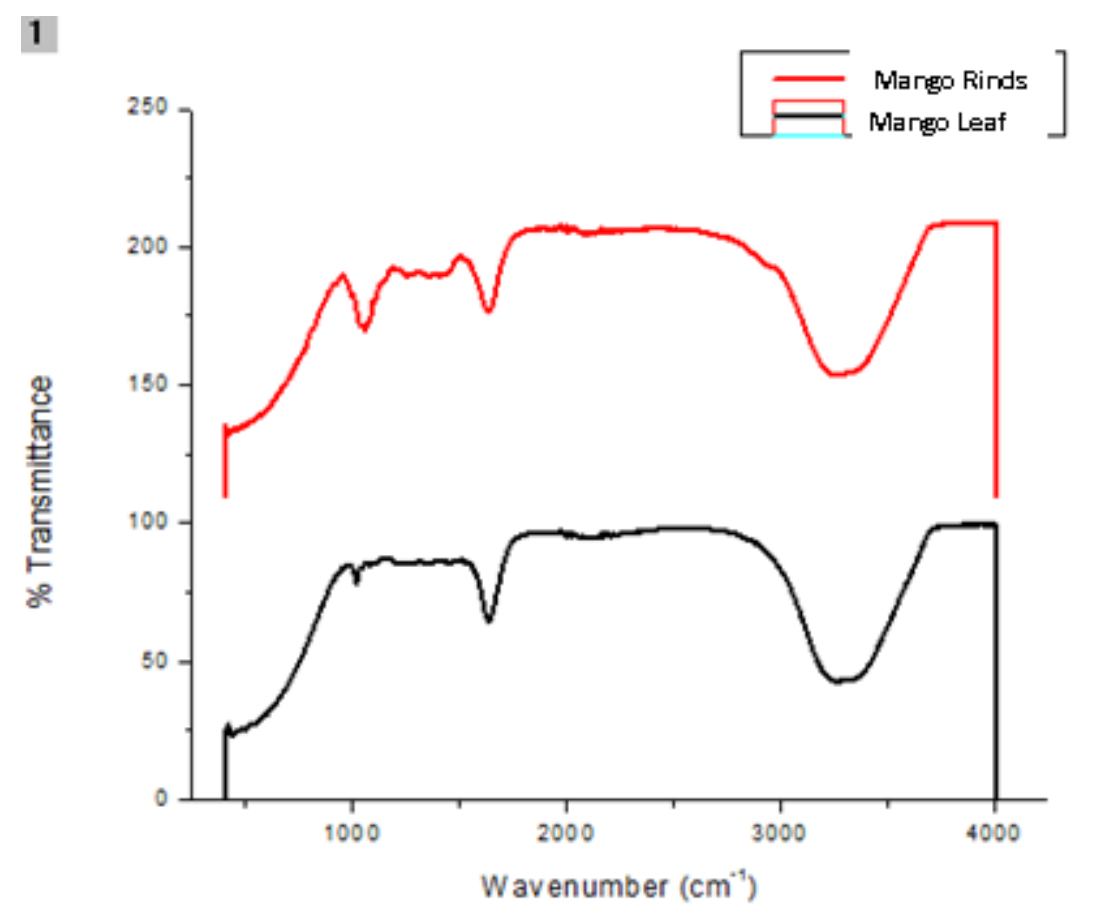

Figure 4. Spectrum FTIR

From the test results of mango leaf extract, there are four peaks. At each peak, there are several functional groups contained therein. The bond at $3271 \mathrm{~cm}^{-1}$ contains an amide and amine compound with an $\mathrm{N}-\mathrm{H}$ functional group. The bond at $2100.95 \mathrm{~cm}^{-1}$ contains an alkane compound with the $\mathrm{C}-\mathrm{H}$ functional group. The bond at $1636.17 \mathrm{~cm}^{-1}$ contains aldehyde compounds, ketones, carboxylic acids, and esters with the functional group $\mathrm{C}=\mathrm{O}$. The bond at $1015.74 \mathrm{~cm}-1$ contains Alkyl Halides and ether compounds with C-F and C-O functional groups. For peak, mango leaf extract produced is almost the same as mango rinds. 


\section{Potentiodynamic Polarization Test Results}

In this test using 3 sets of electrodes including WE (Working Electrode), CE (Counter Electrode) and RE (Reference Electrode).

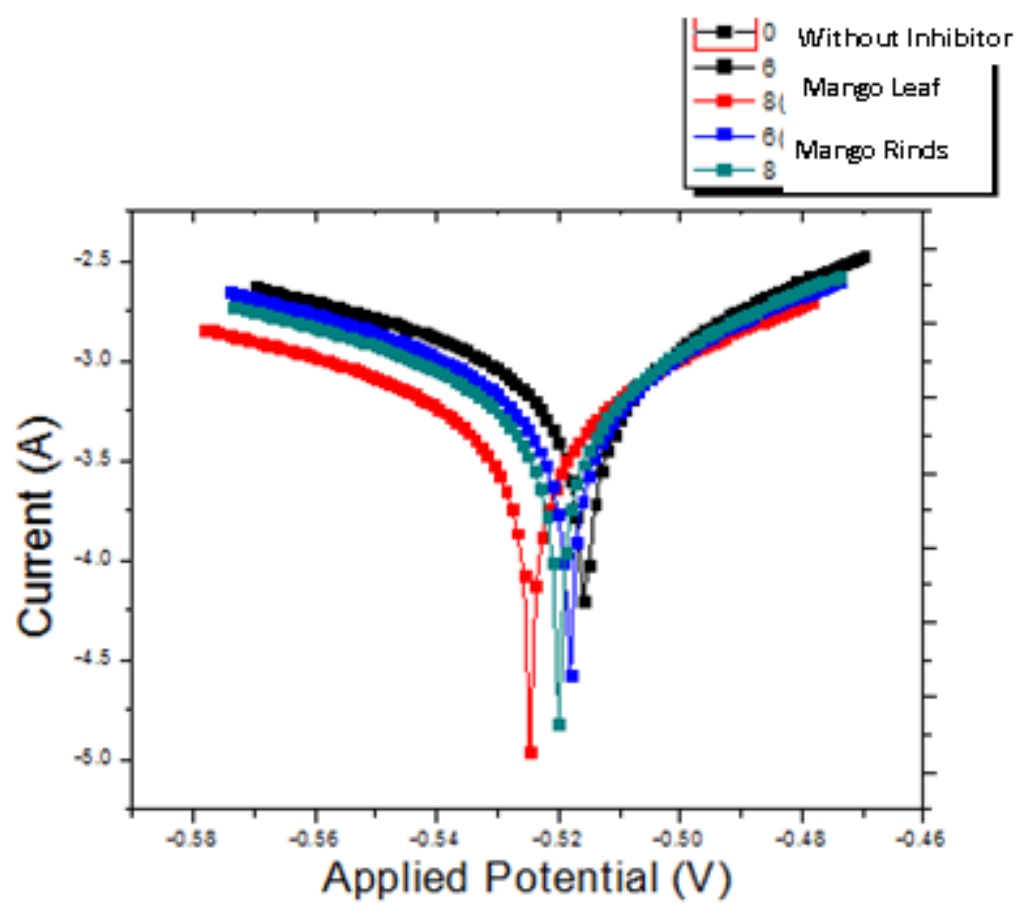

Figure 5. Results of Polarizing Tafel Fittings Without Inhibitor and With Variation of Inhibitor Concentrations

Figure 5 shows that the concentration of mango Leaf and mango rinds Inhibitor affects the position of the tafel curve. Based on the results of fitting, the $8 \mathrm{~mL}$ concentration of mango rinds polarization inhibitor has a very large effectiveness in inhibiting the corrosion rate, then the $6 \mathrm{~mL}$ mango rinds inhibitor and the mango leaf inhibitor with a concentration of 6 and $8 \mathrm{~mL}$, respectively. The shifting of the tafel curve with the application of a corrosion inhibitor downward shows a decrease in the Icorr value so that the corrosion rate decreases. The price of corrosion rate, the highest price of corrosion rate is in the $\mathrm{H}_{2} \mathrm{SO}_{4} 2 \mathrm{M}$ solution without a mixture of inhibitors, which is $0.15589478 \mathrm{~mm} /$ year. The price of the corrosion rate continues to decline until the lowest corrosion rate is at a concentration of $6 \mathrm{~mL}$ with mango leaf inhibitor, which is $0.020521 \mathrm{~mm} /$ year. This is because the mango rinds and mango leaves contain antioxidants which can inhibit the rate of corrosion. 
1

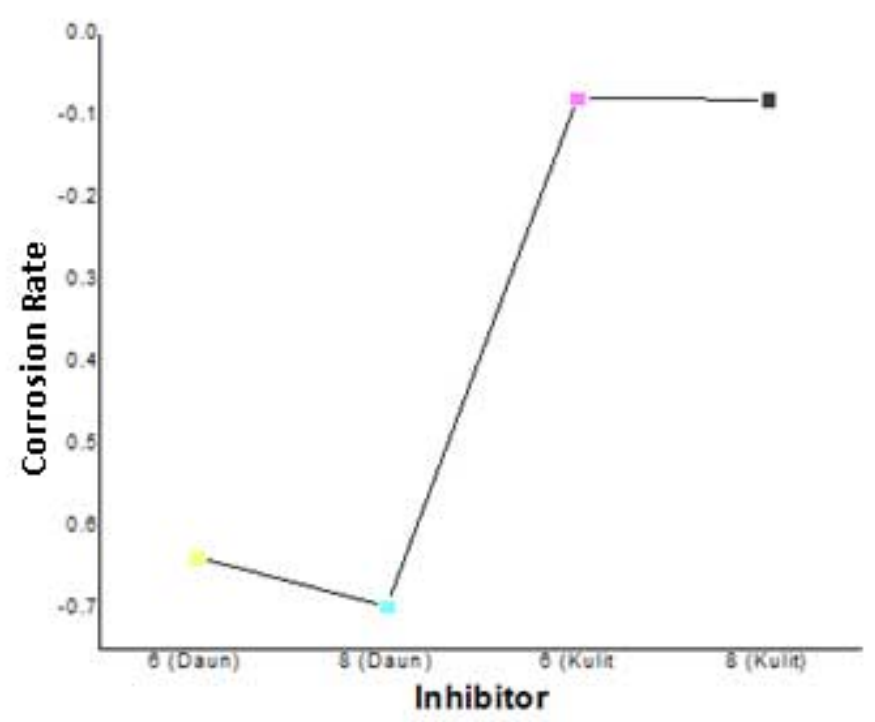

Figure 6. Graph of Mango Leaf and Mango Rinds Inhibitor Corrosion Rate

\section{Result of Weight Loss Testing}

\begin{tabular}{ccccc} 
Inhibitor Concentration & Initial Weight & Final Weight & $\begin{array}{c}\text { Different } \\
\text { Weight }\end{array}$ & $\begin{array}{c}\text { Corosion Rate } \\
\text { (mm/year) }\end{array}$ \\
\hline $8 \mathrm{~mL}$ (Mango Rinds) & 4,99 & 3,15 & 0,34 & 31,784 \\
\hline $6 \mathrm{~mL}$ (Mango Leaf) & 4,99 & 4,65 & 1,84 & 172,01
\end{tabular}

Table 1 shows the weight reduction that occurred in AISI 1070 steel specimen with $8 \mathrm{~mL}$ mango rinds inhibitor and $6 \mathrm{~mL}$ mango leaves treated on $2 \mathrm{M} \mathrm{H}_{2} \mathrm{SO}_{4}$ corrosive medium with 7 days of immersion time, it appears that the specimen pad with mango rinds inhibitor decreased weight by 3.15 grams with a difference in weight of 0.34 , whereas the weight reduction in mango leaf inhibitor is not so significant with the initial weight of 4.65 grams. The corrosion rate value was $31.784 \mathrm{~mm} /$ year, while for mango leaves the corrosion rate showed a fairly large value, namely $172.01 \mathrm{~mm} /$ year. From the value of the corrosion rate obtained, the more inhibitor given is able to inhibit the corrosion rate, and from the results obtained, the mango rinds is able to inhibit the corrosion rate better than mango leaves. 


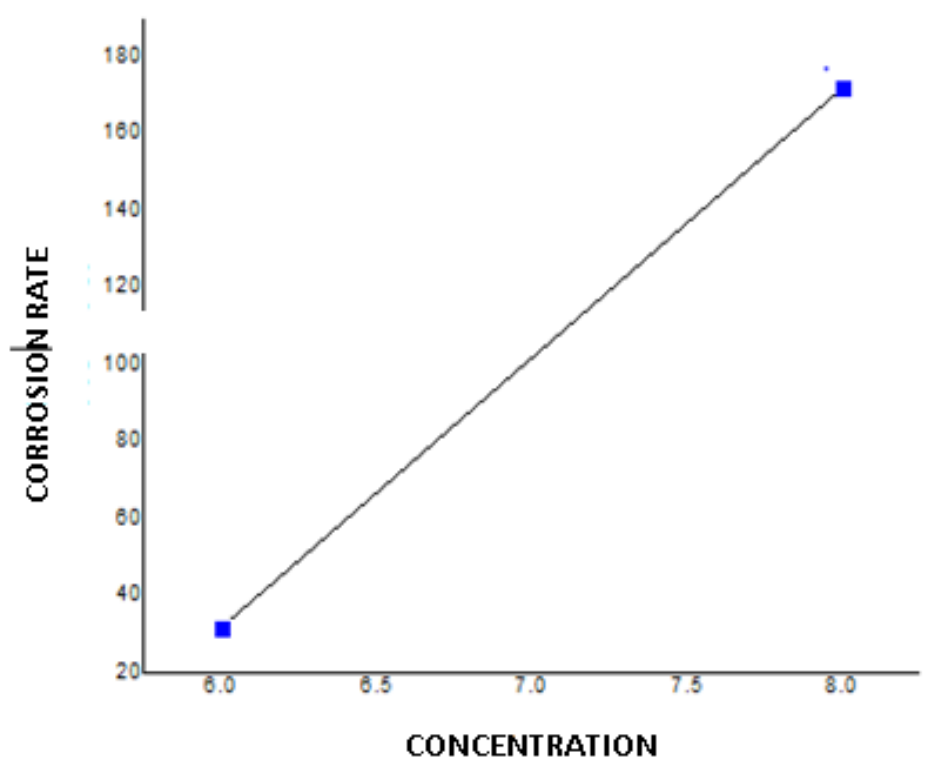

Figure 7. Corrosion Rate Graph using the Weight Loss Method

The addition of an inhibitor can inhibit the corrosive process in AISI 1070 steel material, based on the results of the weight loss method, the greater the concentration of the solution given, the greater the weight of AISI steel material lost. This is because the mango rinds extract given contains flavonoids which can inhibit the corrosion rate, there by reducing the corrosion rate, decreasing the corrosion rate will tend to be constant when it reaches the saturation point.

\section{CONCLUSION}

Mango leaf extract was able to inhibit the corrosion rate well on Steel AISI 1070. This was evidenced by the decrease in the corrosion rate obtained with the respective concentrations of 6 $\mathrm{mL}$ and $8 \mathrm{~mL}$. The $6 \mathrm{~mL}$ inhibitor concentration was able to reduce the corrosion rate quite well. Mango rinds extract is very good at inhibiting the corrosion rate of AISI 1070 Steel. For mango rinds, the greater the inhibitor concentration, the corrosion rate decreases. This proves that the content contained in the mango rinds extract is able to work well in inhibiting the corrosion rate.

\section{REFERENCES}

Dariva, Camila G. Galio, Alexandre F. (2014). Corrosion Inhibitors-Principles, Mechanisms and Applications. INTECH.

Denny A. Jones. (1997). Principlesand Preventation of Corrosion.2nd Edition. Singapore: Prentice Hall International, Inc.

Djaprie, S. (1995). Ilmu dan Teknologi Bahan, ed, Erlangga, Jakarta.

Fatkhurohmat Heru (2014). Application Of Rinds Lime (Citrus Aurantifolia) Extract As Organic Inhibitor For Steel API $5 \mathrm{~L}$ Grade B in $\mathrm{H}_{2} \mathrm{SO}_{4} 1 \mathrm{M}$ Solution. 


\section{DESTRI MULIASTRI ET.AL}

Feng, Lijuan. (2011). Experimental and theoretical studies for corrosion inhibition of carbon steel by imidazoline derivative in $5 \% \mathrm{NaCl}$ saturated $\mathrm{Ca}(\mathrm{OH})_{2}$ solution. Shenyang : Chinese Academy of Sciences.

Harborne, J.B. (1984). Phitochemical Method. Chapman and Hall ltd., London.

Kurniawan, Freddy., Madurani, Kartika., Jul. (2015)."Electrochemical and optical microscopy study of red pepper seed oilcorrosion inhibition by self-assembled monolayers (SAM) on 304 SS". ScienceDirect Progress in Organic Coatings 88 (2015) 256-262.

Pierre R. Roberge. (2008). Corrosion Engineering Principles and Practice. The McGraw-Hill Companies Inc. USA.

Tubagus Noor R., Sari Kusuma W., Agung Purniawan., Budi Agung , Sulistijono (2015). "Effects Of Contentration Of Orange And Mango Rinds Extracts As Corrosion Inhibitor On Carbon Steel In $3.5 \% \mathrm{NaCl}$ Water. 